\title{
What Makes Entrepreneurs Happy? Determinants of Satisfaction Among Founders
}

\author{
Martin A. Carree $\cdot$ Ingrid Verheul
}

Published online: 5 May 2011

(C) The Author(s) 2011. This article is published with open access at Springerlink.com

\begin{abstract}
This study empirically investigates factors influencing satisfaction levels of founders of new ventures, using a representative sample of 1,107 Dutch founders. We relate entrepreneurial satisfaction (with income, psychological burden and leisure time) to firm performance, motivation and human capital. Founders with high levels of specific human capital are more satisfied with income than those with high levels of general human capital. Intrinsic motivation and that of combining responsibilities lowers stress and leads to more satisfaction with leisure time. Women are more satisfied with their income than men, even though they have a lower average monthly turnover.
\end{abstract}

Keywords Satisfaction · Entrepreneurs $\cdot$ Performance $\cdot$ Motivation

JEL Classification $\quad$ J28 $\cdot$ L26 $\cdot$ M13

\section{Introduction}

The majority of entrepreneurs prefer to manage a venture that is successful and that provides them with sufficient financial means to live a comfortable life. For many aspiring entrepreneurs the reality does not meet their initial expectations. In fact, failure rates among start-ups and new ventures can amount up to sixty percent within the first 5 years (Cooper et al. 1988; Phillips and Kirchoff 1989) and the average income of the selfemployed is often well below that of comparable employed individuals (Hamilton 2000).

We are grateful to both referees who helped us to improve our analysis.

\footnotetext{
M. A. Carree $(\bowtie)$

Department of Organisation and Strategy, School of Business and Economics, Maastricht University, P.O. Box 616, 6200 MD Maastricht, The Netherlands

e-mail: m.carree@maastrichtuniversity.nl

I. Verheul

Rotterdam School of Management, Erasmus University, P.O. Box 1738, 3000 DR Rotterdam,

The Netherlands

e-mail: iverheul@rsm.nl
} 
Still, each year there are many individuals who start new firms, indicating that there are other (intrinsic) factors motivating people to pursue an entrepreneurial career. Several studies show that self-employed individuals are more satisfied with their jobs than employees (Benz and Frey 2008a; Blanchflower and Oswald 1998; Bradley and Roberts 2004; Hundley 2001; Katz 1993; Thompson et al. 1992).

The present study examines the factors influencing satisfaction levels among founders. Satisfaction can be seen as a key measure of individual entrepreneurial success. The utility entrepreneurs derive from their start-up venture is an important determinant of venture survival. The degree of entrepreneurial satisfaction is influenced mainly by venture performance, but may also be affected by personal characteristics, motives for start-up and venture characteristics. Existing research on job satisfaction has primarily concentrated on explaining the satisfaction of employees rather than that of entrepreneurs (Cooper and Artz 1995). We contribute to the literature in three ways.

First, we do not use one measure of overall entrepreneurial satisfaction, but discriminate between three different types of satisfaction. This is relevant as there are many facets of (work) satisfaction. Scarpello and Campbell (1983) argue that global measures of job satisfaction are not equivalent to the sum of the different facets. VandenHeuvel and Wooden (1997) present descriptive evidence that the self-employed are more satisfied than wage earners with their independence, but are not with their income and job security. In the present study we empirically examine the determinants of three types of satisfaction among founders, i.e., with income, with psychological well-being, and with leisure time. Satisfaction with income is particularly relevant for entrepreneurs who start a venture to earn a living or for financial success. Furthermore, an entrepreneurial career can be stressful, in particular during the start-up phase. Psychological well-being has previously been studied as an important career outcome for the self-employed (Andersson 2008; Feldman and Bolino 2000; Jamal 1997). Finally, individuals may differ in terms of their satisfaction regarding leisure time. Income and leisure time are the two traditional main sources of utility in economics (Bonke et al. 2009). Some individuals start a business to combine household and work responsibilities and have more flexible working hours. Others start a business with the aim of growing it into a multi-million enterprise, devoting long working hours to the venture, limiting the number of hours available for other (leisure) activities. High time investments in the business may also come at the expense of the family situation as it often leads to higher levels of work-family conflict (Parasuraman and Simmers 2001).

Second, we introduce new additional factors explaining entrepreneurial satisfaction, including start-up motivation, the distinction between general and specific human capital, and venture-specific controls. Start-up motives are likely to impact entrepreneurial satisfaction. Existing research has proposed various motives for new venture creation (e.g., Feldman and Bolino 2000). Individuals who start a business because of 'negative' (push) factors may be less satisfied than those who start because of 'positive' (pull) motives (Jamal 1997; Block and Koellinger 2009). In our study we use two scale measures of motivation: the relative importance of intrinsic motivation, and that of combining work and household/family responsibilities. Also, previous studies have investigated the effect of education on entrepreneurial satisfaction (VandenHeuvel and Wooden 1997; Bradley and Roberts 2004; Clark and Oswald 1996), but thus far have neglected the role of specific types of knowledge and experience. Although education has often been found to negatively affect (job) satisfaction, specific experience may enhance new venture performance and, hence, satisfaction with the newly founded firm. Furthermore, existing research explaining entrepreneurial motivation does not allow for variation between types of ventures in terms of, for example, firm size, complexity of the business environment (e.g., shop around the 
corner versus high-tech companies), and effort and involvement (e.g., full-time versus parttime commitment). Indeed, start-up entrepreneurs tend to have different ambition levels, which may lead to different expectations and subsequent levels of satisfaction.

A third contribution is that we examine a range of indirect effects of venture performance on satisfaction. Although earlier studies control for venture performance and/or income in explaining satisfaction (Cooper and Artz 1995; Bradley and Roberts 2004), we disentangle direct and indirect effects of performance on satisfaction. For example, level of education may have a negative direct effect on satisfaction because of high opportunity costs, while indirectly enhancing satisfaction through increased firm performance.

Although the literature on entrepreneurial satisfaction is relatively scarce, various scholars have linked 'overoptimism' to entrepreneurship (Kahneman and Lovallo 1993; Camerer and Lovallo 1999; Sarasvathy et al. 1998; Arabsheibani et al. 2000). Overoptimism occurs when the expectations of an individual regarding an outcome exceed the realized outcome. Satisfaction may partly be determined by the extent of overoptimism, with the disappointment of overoptimistic entrepreneurs limiting their satisfaction. In this respect, Ferrante (2009) directly connects people's life satisfaction to a (positive) difference between expected and realized outcomes. Several explanations have been proposed for the overoptimistic nature of entrepreneurs. The heuristic of overoptimism may help entrepreneurs to cope with the information (over)load, time pressure and uncertainty of entrepreneurship and to take timely actions, e.g., developing the new venture before all relevant information is available and known (Busenitz and Barney 1997). There is the possibility of self-selection with entrepreneurship attracting a certain type of (overoptimistic) people (Forbes 2005; Åstebro et al. 2007). Overoptimism does not necessarily preclude satisfaction. Entrepreneurs may adjust their expectations ex-post and believe that the entrepreneurial experience is satisfactory despite initial unrealistic expectations. ${ }^{1}$

We examine the determinants of satisfaction among founders using a large representative sample of 1,107 entrepreneurs in The Netherlands who manage new ventures of less than one-year-old. The data set contains information on a wide range of personal and venture characteristics and distinguishes between three facets of satisfaction. Satisfaction with income, leisure time and psychological well-being are important indicators of the amount of 'utility' derived from an occupation and entrepreneurship in specific.

\section{Determinants of Entrepreneurial Satisfaction}

Some entrepreneurs are more satisfied with their ventures than others. In this study we link entrepreneurial satisfaction to performance and four types of factors: human capital (general and specific), start-up motivation, individual-specific and venture-specific control factors. These factors may have both a direct and indirect effect (via performance) on satisfaction. See Fig. 1. In this study we discriminate between three different types of satisfaction: with respect to income, psychological well-being and leisure time.

The first factor is human capital. We expect that entrepreneurs who possess higher levels of specific (or relevant) human capital at the time of start-up have more realistic expectations and, accordingly, are more likely to be content with financial performance or non-monetary utility derived from the business (e.g., psychological well-being, leisure time). The opposite will be true for high levels of general human capital, which are

\footnotetext{
${ }^{1}$ Cooper and Artz (1995) find, in fact, that entrepreneurs who were initially more optimistic were more satisfied later, even when controlling for performance.
} 


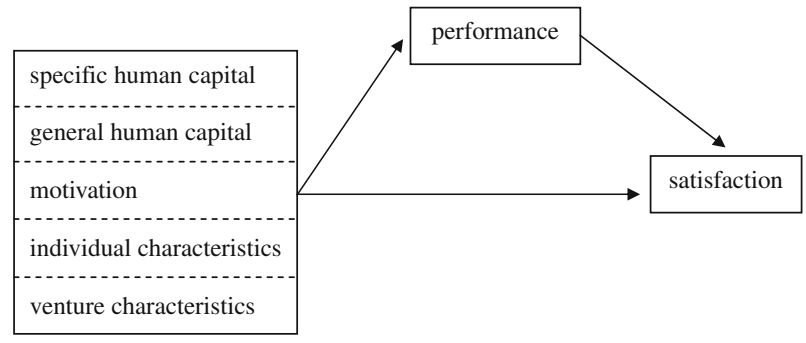

Fig. 1 Explaining entrepreneurial satisfaction

expected to boost the expectations of individual entrepreneurs and make it more difficult to achieve satisfaction. Second, we expect that the motivation for starting up a business will be related to individual satisfaction. Start-up motives of entrepreneurs can have important consequences for the degree of satisfaction as entrepreneurs are expected to evaluate performance by linking firm outcomes to their initial goals and expectations. In addition, we control for individual- and venture-specific characteristics. Next to direct effects on entrepreneurial satisfaction, we take into account that these factors may affect satisfaction through venture performance.

In the remainder of this section we will discuss the determinants of entrepreneurial satisfaction in more detail.

\subsection{Specific and General Human Capital}

Founders differ in terms of the amount of relevant human capital they require and possess. They may start in distinct business environments, requiring different types and levels of knowledge and information. Individuals who are well-informed about the possible consequences of their choices are more likely to be satisfied with the end result. A distinction is usually made between general and specific or relevant human capital, for example, discriminating between education level and experience (Becker 1993; Castanias and Helfat 2001). Education has been found to negatively affect entrepreneurial satisfaction (VandenHeuvel and Wooden 1997; Bradley and Roberts 2004; Clark and Oswald 1996). Highly educated self-confident entrepreneurs may have a hard time meeting their own high expectations and have difficulty compensating for their high opportunity costs. Indeed, Ferrante (2009) finds that higher educated people are more likely to regret forgone opportunities. Also, well-educated entrepreneurs may be more likely to overestimate their abilities to run a venture and become disappointed than entrepreneurs with lower levels of education.

It is important to distinguish between formal education and relevant (or pertinent) human capital (Bhandari and Deaves 2006), the latter which can be acquired through experience with, for example, managerial tasks and the industry. Entrepreneurs who performed related activities in their past career, can be expected to be more realistic (Fraser and Greene 2006; Cooper et al. 1988) and therefore more likely to be satisfied. Nevertheless, experience may not always enhance satisfaction. Bradley and Roberts (2004) do not find a significant effect of entrepreneurial experience on satisfaction levels of entrepreneurs. Wright et al. (1997) indicate that serial entrepreneurs are less able to recognize their own limitations than first-time entrepreneurs. In addition, Hayward et al. (2006, p. 165) claim that experienced founders may be overconfident when the nature of their venture differs from that of previous endeavors. 


\subsection{Start-Up Motivation}

Salinas-Jiménez (2010) argue that differences in motivations have an important effect on levels of satisfaction and that moving from extrinsic to intrinsic motivation leads to greater satisfaction (with life). There are various motives for new venture creation (Gilad and Levine 1986; Feldman and Bolino 2000). In addition to the financial benefits of starting up a business, there are several non-pecuniary rewards, including the wish to be independent, the entrepreneurial challenge and the possibility of combining work and household responsibilities (Amit et al. 2001). Hamilton (2000) claims that these non-pecuniary benefits of self-employment must be substantial as the pecuniary rewards are often disappointing. Two important intrinsic start-up motives include that of being your own boss and the challenge of entrepreneurship (Feldman and Bolino 2000). Individuals who are motivated by these non-pecuniary benefits will probably be less disappointed by unexpected financial hardship or unforeseen stress and excessively long working hours. Cooper and Artz (1995) find that non-monetary goals positively relate to satisfaction. Similarly, Benz and Frey (2004, 2008b) find the greater independence and autonomy of selfemployment increases job satisfaction. Finally, according to Jamal (1997, p. 55) individuals who are 'pushed' into self-employment because no other job was available, may experience less satisfaction. This result was recently confirmed by Block and Koellinger (2009) for German nascent entrepreneurs.

The combination of work and household responsibilities appears an important consideration at firm start-up for a substantial number of entrepreneurs, but in particular for women (Wellington 2006, p. 359). The motive of combining responsibilities may especially lead to more satisfaction with leisure time and flexibility of working hours. ${ }^{2}$ Individuals who start a business from the perspective of combining responsibilities may be better aware of and prepared for the necessary time investments in entrepreneurship.

\subsection{Performance}

Next to the direct effects on satisfaction, we test for indirect effects through firm performance. Firm performance is an obvious determinant of satisfaction with the venture (e.g., Cooper and Artz 1995). This is in line with the positive income effect on job satisfaction, specifically satisfaction with respect to pay (Gazioglu and Tansel 2006). An obvious example of an indirect effect through venture performance on satisfaction with income is that of general human capital. It is also sometimes claimed that women entrepreneurs financially underperform vis-à-vis their male counterparts, which could again negatively affect their satisfaction with income.

\subsection{Individual-Specific Controls}

Several studies have investigated the effect of socio-demographic factors such as age, family situation and gender, on job and life satisfaction. We take these factors into account when explaining entrepreneurial satisfaction. Furthermore, we incorporate the element of risk tolerance to control for differences in coping with business (mis)fortune across entrepreneurs. We include the following four individual-specific controls in the analysis:

\footnotetext{
${ }^{2}$ Parasuraman and Simmers (2001) emphasize that there may also be challenges associated with combining work and family responsibilities.
} 


\subsubsection{Gender}

There may be a gender bias in expectations regarding the performance of the newly founded venture. Several studies show that women report higher levels of job satisfaction than men do (VandenHeuvel and Wooden 1997; Clark 1997; Clark et al. 1996). Similarly, Cooper and Artz (1995) find that female entrepreneurs are, ceteris paribus, more satisfied with the business than their male counterparts. Gender differences in overconfidence appear to be highly task-dependent (Lundeberg et al. 1994) and greatest for tasks that are perceived to be masculine, such as entrepreneurship (Beyer and Bowden 1997). Gazioglu and Tansel (2006) also point out that there may be a participation effect, i.e., women are often secondary bread-winner, and may sooner opt for exit when dissatisfied.

\subsubsection{Age}

A U-shaped relationship between age and satisfaction has been found for both wage- and self-employed individuals (Clark et al. 1996; VandenHeuvel and Wooden 1997; Bradley and Roberts 2004; Gazioglu and Tansel 2006). Higher levels of reported job satisfaction among older workers may reflect seniority-related benefits, lower job expectations and self-selection effects. Indeed, Forbes (2005) provides evidence that overconfidence, and a subsequent higher chance of being dissatisfied, is more prevalent among younger than older entrepreneurs. ${ }^{3}$

\subsubsection{Life Partner}

A life partner may reduce stress related to the business by sharing problems and (s)he may earn an income that provides the entrepreneur with financial security. Clark et al. (1996) find that married employees experience higher levels of job satisfaction, in particular in terms of satisfaction with pay. Blanchflower and Oswald (1998) report a positive effect of marriage on overall happiness, which is valid for all employed individuals (wage- or selfemployed). ${ }^{4}$ In addition, they find negative effects of being without a partner as is found in the case of widowed, divorced or separated individuals.

\subsubsection{Risk Tolerance}

Entrepreneurs on average have a higher level of risk tolerance than employees (Kihlstrom and Laffont 1979). However, even among entrepreneurs risk tolerance may vary considerably. Risk tolerant entrepreneurs may be more likely to appreciate disappointing business results as a possible side effect of the entrepreneurial adventure. Parker (2006, p. 353) argues that risk averse entrepreneurs feel pressured to work longer hours to avoid poor performance and therefore may also be less content with psychological well-being and available leisure time. Block and Koellinger (2009) present some evidence that risk tolerance is positively related to start-up satisfaction.

\footnotetext{
${ }^{3}$ Cooper and Artz (1995) did not find evidence for a relationship between age and satisfaction of entrepreneurs.

${ }^{4}$ Nevertheless, Arabsheibani et al. (2000) do not find an effect of marital status on overoptimism among the self-employed.
} 


\subsection{Venture-Specific Controls}

The effect of characteristics of the newly founded business on entrepreneurial satisfaction thus far did not receive any attention in the literature. Nevertheless, it can be expected that the nature of the business affects the degree of entrepreneurial satisfaction. In the present study we discriminate between three key venture characteristics:

\subsubsection{Size}

Larger new ventures usually come with higher responsibility and expectations and may also involve more stress. On the other hand, large start-ups usually require more preparation and have to deal with outside supervision, e.g., by capital suppliers, thereby reducing the chance of unexpected misfortune. As measures of firm size we include the number of employees, the amount of start-up capital, and whether the business operates from the home or a separate business premises. Starting and running a business from the home may be an indicator of prudence on the part of the entrepreneur, and may affect perceived psychological stress and leisure time.

\subsubsection{Complexity}

Greater environmental complexity may lead to less satisfaction as the entrepreneur is confronted with multiple sources of unexpected setback. In addition, managers who introduce pioneering products tend to be more overoptimistic than those who pursue incremental innovations (Simon and Houghton 2003), diminishing subsequent entrepreneurial satisfaction. We use two measures of complexity: whether the start-up is in a hightech sector, and whether the entrepreneur believes (s)he is able to keep up with all relevant developments.

\subsubsection{Involvement}

The allocation of time to various entrepreneurial tasks may vary considerably across startups. Entrepreneurs who are confronted with substantial time pressure may derive less satisfaction from their enterprise. This is in line with the negative effect of working hours on job satisfaction as reported by, e.g., Clark et al. (1996) and Gazioglu and Tansel (2006). We expect that entrepreneurs who are dependent upon the income out of the firm for subsistence show more commitment than 'part-time' entrepreneurs. Demanding sideactivities may increase time pressure and stress, while the opposite holds for outsourcing of tasks.

\section{Methodology}

\subsection{Data}

We use data of a unique and detailed panel survey of the research institute EIM, which was commissioned by the Dutch Ministry of Economic Affairs. A large and representative sample was drawn of independent new ventures registered at the Chamber(s) of Commerce in the first half year of 1994 in the Netherlands. This has been the most extensive sample in terms of available information across the years of sampling. The distribution of firms was 
representative across sector and size class. Only main establishments were selected. The following firms were excluded: agricultural firms and companies extracting minerals, businesses that changed legal form or activity, and relocated firms. About 12,000 firms were approached by telephone of which approximately 3,000 participated in the survey. These firms received a questionnaire by mail. Of these questionnaires 1,938 were completed and returned, mainly by firms that were in existence between 6 months and 1 year. The present study uses the subset of 1,107 entrepreneurs who are either owners or ownermanagers and for which information is available for all variables included in the present study.

\subsection{Measuring Entrepreneurial Satisfaction}

We use a single-item measure of the degree of satisfaction, asking entrepreneurs whether the outcomes of their new venture are in line with their initial expectations. Answer categories range from (1) "much worse than expected" to (5) "far better than expected". Similar measures of self-reported satisfaction have been applied in the areas of customer satisfaction (Peterson and Wilson 1992), self-employment satisfaction (VandenHeuvel and Wooden 1997), and job satisfaction (Wanous et al. 1997). Both Wanous et al. (1997) and Scarpello and Campbell (1983) argue that a single-item measure of overall job satisfaction is preferable to a measure combining items. The present study interprets the answers as cardinal. Ferrer-i-Carbonell and Frijters (2004) show that using the measures as either cardinal or ordinal hardly affects the results of estimations of the determinants of happiness.

Our measure of satisfaction is a relative one, capturing how founders evaluate the current situation (actual experience) with what they initially expected. We consider a person who has his or her expectations on running a business (clearly) not met, met or even (clearly) exceeded as (very) unsatisfied, neutral or (very) satisfied, respectively. Recent studies on satisfaction that compare the actual situation with what could be expected, include Stutzer (2004); Senik (2009) and Boes et al. (2010). They show that the comparison of an individual's own income with that of their parents, peers or with what they earned in the past, is an important driver of subjective well-being.

The outcomes of the new venture after 1 year of operation can be expressed in terms of income, psychological burden or leisure time, which are separately measured in the survey. Correlations between the three different variables of satisfaction indicate that these are related, yet separate, constructs. The correlation coefficient is highest for the relationship between satisfaction with leisure time and that with psychological burden, and amounts to $0.352(p<0.01)$. Satisfaction with income is relatively different from that with psychological burden and leisure time as correlation coefficients amount to $0.212(p<0.01)$ and $0.075(p<0.05)$, respectively.

\subsection{Independent Variables}

An overview of the independent variables can be found in Table 1. The effect of general human capital on satisfaction is tested by way of two variables: Education and EntExperience. The latter variable captures general experience with entrepreneurial activity. We control for the effect of more specific entrepreneurial experience by including the job similarity variable. The effect of specific human capital is tested using the variables JobSimilarity and FinManExperience. We combine the two motivations of 'the wish to be independent' and 'the challenge of starting and running a business' into one variable: 
Table 1 Variable description

\begin{tabular}{|c|c|c|c|c|c|}
\hline Variable name & Variable description & Mean & Std. & $\min$ & $\operatorname{Max}$ \\
\hline $\begin{array}{l}\text { Satisfaction with } \\
\text { respect to income }\end{array}$ & $\begin{array}{l}\text { Thus far, is the income you retrieved from your business } \\
\text { in line with your expectations? }[1=\text { much worse than } \\
\text { expected; } 2=\text { a bit disappointing; } 3=\text { similar to } \\
\text { expectations; } 4=\text { better than expected; } 5=\text { far better } \\
\text { than expected] }\end{array}$ & 3.16 & 0.87 & 1 & 5 \\
\hline $\begin{array}{l}\text { Satisfaction with } \\
\text { respect to psych. } \\
\text { burden }\end{array}$ & $\begin{array}{l}\text { Thus far, is the psychical burden of starting up a business } \\
\text { in line with your expectations? }[1=\text { much worse than } \\
\text { expected; } 2=\text { a bit disappointing; } 3=\text { similar to } \\
\text { expectations; } 4=\text { better than expected; } 5=\text { far better } \\
\text { than expected] }\end{array}$ & 3.24 & 0.87 & 1 & 5 \\
\hline $\begin{array}{l}\text { Satisfaction with } \\
\text { respect to leisure } \\
\text { time }\end{array}$ & $\begin{array}{l}\text { Thus far, is your (remaining) leisure time in line with } \\
\text { your expectations? }[1=\text { much worse than expected; } \\
2=\text { a bit disappointing; } 3=\text { similar to expectations; } \\
4=\text { better than expected; } 5=\text { far better than } \\
\text { expected] }\end{array}$ & 3.03 & 0.91 & 1 & 5 \\
\hline Performance & 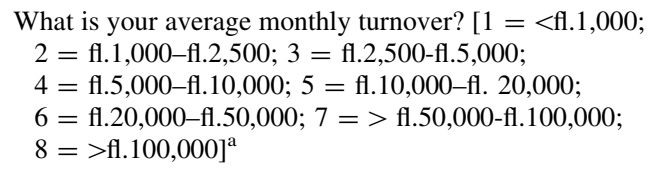 & 3.18 & 1.91 & 1 & 8 \\
\hline Education & $\begin{array}{l}\text { What is your highest level of education? }[1=\text { average } \\
\text { second. education; } 2=\text { higher second. education; } \\
3=\text { low-level vocat. training; } 4=\text { Leerlingstelsel }^{\mathrm{c}} \text {; } \\
5=\text { mid-level vocat. training; } 6=\text { high-level vocat. } \\
\text { training; } 7=\text { university }]\end{array}$ & 4.39 & 1.85 & 1 & 7 \\
\hline EntExperience & $\begin{array}{l}\text { Did you run a business prior to the start-up of this firm? } \\
\quad[0=\text { no; } 1=\text { yes }]\end{array}$ & 0.08 & 0.28 & 0 & 1 \\
\hline JobSimilarity & $\begin{array}{l}\text { To what extent are your current activities related to past } \\
\text { work? }[1=\text { not at all; } 2=\text { somewhat similar; } \\
3=\text { identical }]\end{array}$ & 2.01 & 0.76 & 1 & 3 \\
\hline FinManExperience & $\begin{array}{l}\text { Did you have experience with financial management } \\
\text { prior to the start-up of this firm? }[1=\text { no; } 2=\text { a little; } \\
3=\text { quite some; } 4=\text { a lot }]\end{array}$ & 2.04 & 0.97 & 1 & 4 \\
\hline Intrinsic & $\begin{array}{l}\text { To what extent did intrinsic motives play a role in the } \\
\text { start-up decision? Calculated as the importance of two } \\
\text { intrinsic motives (wish to be your own boss; challenge) } \\
\text { as a share of the importance of all other motives }\end{array}$ & 0.24 & 0.05 & 0.10 & 0.38 \\
\hline Combine & $\begin{array}{l}\text { To what extent did the combination of work and } \\
\text { household responsibilities play a role in the start-up } \\
\text { decision? Calculated as the importance of combining } \\
\text { responsibilities as a share of the importance of all other } \\
\text { motives }^{\text {b }}\end{array}$ & 0.08 & 0.03 & 0.03 & 0.20 \\
\hline Female & Are you male or female? $[0=$ male; $1=$ female $]$ & 0.27 & 0.45 & 0 & 1 \\
\hline Age & $\begin{array}{l}\text { Age in categories }[1=<20 ; 2=20-24 ; 3=25-29 \\
\quad \begin{array}{l}4=30-34 ; 5=35-39 ; 6=40-44 ; 7=45-49 \\
8=50-54 ; 9=55-59 ; 10=>60]\end{array}\end{array}$ & 4.59 & 1.72 & 1 & 10 \\
\hline LifePartner & Do you have a life partner? $[0=$ no; $1=$ yes $]$ & 0.82 & 0.38 & 0 & 1 \\
\hline RiskTolerance & $\begin{array}{l}\text { To what extent do you dare to take risk? }[1=\text { very } \\
\text { weak...5 = very strong] }\end{array}$ & 3.77 & 0.80 & 1 & 5 \\
\hline Employees & $\begin{array}{l}\text { How many employees do you have? (in FTEs }=\text { people } \\
\text { who work more than } 32 \mathrm{~h} \text { per week) }\end{array}$ & 0.35 & 1.60 & 0 & 21 \\
\hline
\end{tabular}


Table 1 continued

\begin{tabular}{|c|c|c|c|c|c|}
\hline Variable name & Variable description & Mean & Std. & $\min$ & $\operatorname{Max}$ \\
\hline Subsistence & $\begin{array}{l}\text { To what extent are you dependent on the profits from } \\
\text { your business for subsistence? }[1=\text { not at } \\
\text { all...4 = completely] }\end{array}$ & 2.23 & 1.18 & 1 & 4 \\
\hline OtherHours & $\begin{array}{l}\text { At the start of your firm, how much time did you spend } \\
\text { on other activities? }[0=0 ; 1=1-9 ; 2=10-19 \\
3=20-39 ; 4=>40 \mathrm{~h}]\end{array}$ & 1.59 & 1.67 & 0 & 4 \\
\hline FirmStatus & $\begin{array}{l}\text { What is the status of your firm? }[1=\text { newly started firm; } \\
2=\text { restart existing firm; } 3=\text { take-over }]\end{array}$ & 1.24 & 0.63 & 1 & 3 \\
\hline StartCapital & 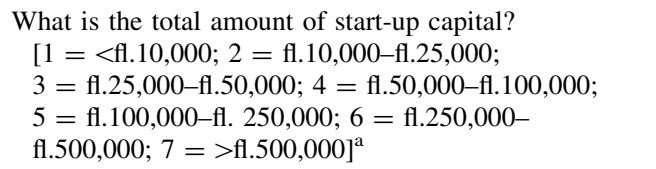 & 2.13 & 1.46 & 1 & 7 \\
\hline Outsourcing & $\begin{array}{l}\text { Are certain activities within the firm contracted out? } \\
{[0=\text { no; } 1=\text { yes }]}\end{array}$ & 0.44 & 0.50 & 0 & 1 \\
\hline HomeBase & $\begin{array}{l}\text { Do you run your business from the home? }[0=\text { no; } \\
1=\text { yes }]\end{array}$ & 0.69 & 0.46 & 0 & 1 \\
\hline ManuCons & $\begin{array}{l}\text { Do you run a business in manufacturing or construction? } \\
{[0=\text { no; } 1=\text { yes }]^{\mathrm{d}}}\end{array}$ & 0.12 & 0.33 & 0 & 1 \\
\hline WholeRetail & $\begin{array}{l}\text { Do you run a business in wholesale or retailing? } \\
{[0=\text { no; } 1=\text { yes }]^{\mathrm{d}}}\end{array}$ & 0.30 & 0.46 & 0 & 1 \\
\hline KeepUp & $\begin{array}{l}\text { Are you able to keep up with all relevant developments } \\
\text { in your line of business? }[1=\text { not really...4 } 4=\text { to a } \\
\text { large extent }]\end{array}$ & 3.17 & 0.71 & 1 & 4 \\
\hline Hightech & $\begin{array}{l}\text { Is the sector you operate in characterized by rapid } \\
\text { technological developments? }[1=\text { no; } 2=\text { somewhat; } \\
3=\text { yes }]\end{array}$ & 1.48 & 0.74 & 1 & 3 \\
\hline
\end{tabular}

\footnotetext{
a Measured in Dutch guilders (florin). One guilder is equivalent to 0.45 Euro

b Other motives include: (risk of) unemployment; dissatisfaction with wage job; opportunity to leave wage job with bonus or taking along customers; available own funding; grown into it; exploiting profit opportunity; earn more money than in wage employment; combine responsibilities; no other choice. The respondents could rate them as follows: $1=$ not important; $2=$ to some extent; $3=$ very important

c Here students combine school with a minimum of $20 \mathrm{~h}$ work

d The category 'personal and business services' is the base category
}

Intrinsic. This variable represents the extent to which these two main intrinsic motives play a role in the start-up decision. ${ }^{5}$ The variable Combine captures the extent to which the combination of responsibilities plays a role in the start-up decision. ${ }^{6}$ Performance is measured in terms of average monthly turnover.

\footnotetext{
5 The two motives of 'challenge of starting and running a business' and 'the wish to be independent' score clearly as most often mentioned important start-up motives in our survey data. Their average scores are close to 2.5 (on a scale from 1 to 3 ). The two motive variables are highly correlated and, hence, they were combined into one variable.

${ }^{6}$ Note that the respondents could indicate more than one start-up motive in the questionnaire. Other motives include (threat of) unemployment, dissatisfaction with the current wage job, self-employment due to an occupation (e.g. dentist), perception of a market opportunity and taking over the family business.
} 


\subsection{Control Variables}

We include the following control variables in our analysis. The personal characteristics are measured by a gender dummy, Female, an Age variable and the square of this variable, a LifePartner dummy variable and self-reported risk attitude, RiskTolerance, respectively. The venture characteristics are the following. Employees represents the number of fulltime employees. Subsistence captures the extent to which entrepreneurs are dependent on the financial revenues from the business. OtherHours represents the time spent on sideactivities (e.g., family care, hobbies, schooling). FirmStatus measures whether the firm is newly started, restarted, or a takeover of an existing business. We control for size differences across the young firms in our sample by taking into account the amount of start-up capital, StartCapital. This is a categorical variable with seven size classes, ranging from relatively small $(<4,500$ Euro) to substantial start-ups $(>225,000$ Euro). The variable Outsourcing measures the degree to which entrepreneurs contract out certain activities. HomeBase measures whether a business is run from the home or business premises. ManuCons and WholeRetail capture industry effects. We distinguish between three types of industries: 'manufacturing and construction' (ManuCons); 'wholesale and retailing' (WholeRetail) and the base category of 'other industries' (mainly personal services). Finally, we control for the dynamics of the business environment and required knowledge by including two variables: KeepUp, indicating the extent to which entrepreneurs are able to keep up with relevant developments in their line of business, and Hightech, capturing the degree of technological advancement in the sector.

\section{Analysis and Results}

The results of the OLS regression explaining satisfaction are presented in Table $2 .^{7}$ The explanatory power of the models for the three types of satisfaction is limited. This is in line with relatively low $\mathrm{R}^{2} \mathrm{~s}$ in previous studies explaining job satisfaction (e.g. FuchsSchündeln 2009; Blanchflower and Oswald 1998; Bradley and Roberts 2004). The general human capital variables Education and EntExperience have the expected negative effect on satisfaction with income. Entrepreneurial experience also seems to limit satisfaction with psychological burden. The specific human capital variables of job similarity and experience with financial management significantly increase satisfaction with income and with leisure time, respectively.

We find that intrinsic motives only enhance satisfaction with psychological well-being. Thus, founders appear better able to cope with stress when intrinsically motivated. We do not find a significant relationship between intrinsic motivation and satisfaction with income and leisure time. Entrepreneurs motivated by combining work and family care score higher on all three facets of satisfaction. Apparently, entrepreneurs who balance work and family care are well aware of the demands of self-employment, and benefit from having more flexible working hours. This is in line with Hamilton (2000) arguing that entrepreneurs enjoy the non-pecuniary benefits of self-employment.

\footnotetext{
7 We also estimated an ordered logit model because of the categorical nature of the dependent variable. The estimation results are very similar to the OLS results. See also Ferrer-i-Carbonell and Frijters (2004). There are exceptions only for two control variables. Subsistence is significantly positive $(p=0.05)$ in the ordered logit model for satisfaction with income, while it was not significant in the OLS estimation. HomeBases is not significant in the ordered logit model for satisfaction with leisure time $(p=0.11)$, while it is significantly positive in the OLS model.
} 
Table 2 Explaining satisfaction with income, psychological burden, leisure time

\begin{tabular}{|c|c|c|c|c|c|c|}
\hline \multirow[b]{3}{*}{ Constant } & \multicolumn{6}{|c|}{ Satisfied with... } \\
\hline & \multicolumn{2}{|l|}{ Income } & \multicolumn{2}{|c|}{ Psychological burden } & \multicolumn{2}{|l|}{ Leisure time } \\
\hline & $1.838 * * *$ & $(6.0)$ & $2.051 * * *$ & $(6.4)$ & $2.732 * * *$ & $(8.2)$ \\
\hline Performance & $0.144 * * *$ & $(7.1)$ & $-0.036^{*}$ & $(-1.7)$ & $-0.089 * * *$ & $(-4.1)$ \\
\hline Education & $-0.033 * *$ & $(-2.3)$ & 0.002 & $(0.1)$ & 0.008 & $(0.5)$ \\
\hline EntExperience & $-0.157 *$ & $(-1.7)$ & $-0.177^{*}$ & $(-1.8)$ & -0.050 & $(-0.5)$ \\
\hline JobSimilarity & $0.099 * * *$ & $(2.7)$ & -0.001 & $(-0.0)$ & 0.024 & $(0.6)$ \\
\hline FinManExperience & 0.020 & $(0.7)$ & 0.036 & $(1.3)$ & $0.067 * *$ & $(2.3)$ \\
\hline Intrinsic & 0.313 & $(0.6)$ & $1.214 * *$ & $(2.2)$ & 0.572 & $(1.0)$ \\
\hline Combine & $1.320 *$ & $(1.7)$ & $1.778 * *$ & $(2.1)$ & $3.047 * * *$ & $(3.5)$ \\
\hline Female & $0.110^{*}$ & $(1.7)$ & $-0.199 * * *$ & $(-3.0)$ & $-0.127 *$ & $(-1.8)$ \\
\hline Age & -0.024 & $(-0.3)$ & 0.094 & $(1.2)$ & 0.006 & $(0.1)$ \\
\hline $\mathrm{Age}^{2}$ & 0.001 & $(0.1)$ & -0.005 & $(-0.7)$ & -0.001 & $(-0.2)$ \\
\hline LifePartner & 0.042 & $(0.6)$ & 0.040 & $(0.5)$ & 0.092 & $(1.2)$ \\
\hline RiskTolerance & $0.080 * *$ & $(2.4)$ & $0.103 * * *$ & $(3.0)$ & 0.010 & $(0.3)$ \\
\hline Employees & -0.016 & $(-0.9)$ & -0.001 & $(-0.0)$ & 0.010 & $(0.5)$ \\
\hline Subsistence & 0.035 & (1.3) & -0.034 & $(-1.2)$ & 0.020 & $(0.7)$ \\
\hline OtherHours & $0.032^{*}$ & (1.8) & -0.026 & $(-1.4)$ & $-0.058 * * *$ & $(-3.0)$ \\
\hline FirmStatus & -0.045 & $(-1.0)$ & 0.030 & $(0.6)$ & $-0.157 * * *$ & $(-3.0)$ \\
\hline StartCapital & $-0.057 * *$ & $(-2.5)$ & -0.031 & $(-1.3)$ & $0.048 *$ & (1.9) \\
\hline Outsourcing & 0.038 & $(0.7)$ & 0.016 & $(0.3)$ & -0.031 & $(-0.5)$ \\
\hline HomeBase & 0.094 & $(1.4)$ & 0.018 & $(0.3)$ & $0.123^{*}$ & $(1.7)$ \\
\hline ManuCons & -0.081 & $(-1.0)$ & -0.043 & $(-0.5)$ & -0.030 & $(-0.3)$ \\
\hline WholeRetail & $-0.239 * * *$ & $(-4.0)$ & -0.076 & $(-1.2)$ & -0.012 & $(-0.2)$ \\
\hline KeepUp & $0.144 * * *$ & $(4.0)$ & $0.098 * * *$ & $(2.6)$ & 0.028 & $(0.7)$ \\
\hline Hightech & -0.056 & $(-1.6)$ & -0.024 & $(-0.6)$ & $-0.065^{*}$ & $(-1.7)$ \\
\hline $\mathrm{N}$ & 1,107 & & 1,107 & & 1,107 & \\
\hline $\mathrm{R}^{2}$ & 0.133 & & 0.051 & & 0.070 & \\
\hline
\end{tabular}

* Refer to significance levels of 0.10 (two-sided test)

** Refer to significance levels of 0.05 (two-sided test)

*** Refer to significance levels of 0.01 (two-sided test)

$t$ values are presented between brackets

Women and men clearly differ regarding satisfaction with their new venture. Women appear more satisfied with income than men, but are less content with the lack of available leisure time and the psychological demands of running a new business. The latter result is in line with previous evidence that women tend to be more vulnerable to (di)stress (Vermeulen and Mustard 2000). Neither Age nor LifePartner have an effect on satisfaction. Entrepreneurs who report high risk tolerance also indicate to be more satisfied with income and psychological burden. These entrepreneurs appear less upset when confronted with low business performance.

There are several interesting effects of the venture-specific control variables. A takeover reduces rather than enhances satisfaction with leisure time. Entrepreneurs seem to underestimate the challenges of running a business perhaps assuming that an existing 
Table 3 Explaining performance (average monthly turnover)

\begin{tabular}{lcl}
\hline & Coefficient & $t$ value \\
\hline Constant & -0.280 & $(-0.6)$ \\
Education & 0.015 & $(0.7)$ \\
EntExperience & 0.039 & $(0.3)$ \\
JobSimilarity & $0.234^{* * *}$ & $(4.3)$ \\
FinManExperience & 0.060 & $(1.5)$ \\
Intrinsic & -0.434 & $(-0.6)$ \\
Combine & -1.227 & $(-1.0)$ \\
Female & $-0.413^{* * *}$ & $(-4.3)$ \\
Age & 0.024 & $(0.2)$ \\
Age & -0.001 & $(-0.1)$ \\
LifePartner & $0.496^{* * *}$ & $(4.7)$ \\
RiskTolerance & 0.065 & $(1.3)$ \\
Employees & $0.170^{* * *}$ & $(6.5)$ \\
Subsistence & $0.285^{* * *}$ & $(7.4)$ \\
OtherHours & $-0.168^{* * *}$ & $(-6.3)$ \\
FirmStatus & $0.477^{* * *}$ & $(6.8)$ \\
StartCapital & $0.384^{* * *}$ & $(11.6)$ \\
Outsourcing & $0.416^{* * *}$ & $(5.3)$ \\
HomeBase & $-0.260^{* * *}$ & $(-2.6)$ \\
ManuCons & $0.375^{* * *}$ & $(3.0)$ \\
WholeRetail & $0.292^{* * *}$ & $(3.3)$ \\
KeepUp & $0.144^{* * *}$ & $(2.7)$ \\
Hightech & -0.031 & $(-0.6)$ \\
N & 1,107 & \\
$\mathrm{R}^{2}$ & 0.590 & \\
\hline
\end{tabular}

* Refer to significance level of 0.10 (two-sided test)

** Refer to significance level of 0.05 (two-sided test)

*** Refer to significance level of 0.01 (two-sided test)

business requires less time and effort than creating a new venture. Entrepreneurs who start new ventures with a sizeable amount of start-up capital are less satisfied with income even when firm performance is corrected for. Apparently, it is difficult to achieve a satisfactory rate of return on invested capital in the first year after start-up. Entrepreneurs who start wholesale and retail firms appear less content with income than entrepreneurs in other sectors. This might be related to relatively low entry barriers, and therefore higher competition, in these sectors. ${ }^{8}$ Finally, environmental complexity lowers the level of satisfaction: entrepreneurs who run high-tech firms and who have difficulty keeping up with relevant industry developments are on average less content.

Performance has a positive effect on satisfaction with income. Firm performance also has a significant effect on the two non-pecuniary types of satisfaction. Remarkably, this effect is negative, although only significant at the 10 percent level for psychological well-

${ }^{8}$ The year before the survey there was a substantial lowering of institutional entry requirements in the Netherlands which led to more entry (Carree and Nijkamp 2001). 
being. Apparently, financial success comes at a price. Table 3 shows the OLS regression results explaining firm performance. ${ }^{9}$ Six variables with significant direct effects on satisfaction with income, also significantly influence performance. These are JobSimilarity, Female, OtherHours, StartCapital, WholeRetail and KeepUp. There are also variables that only have an indirect impact on satisfaction. These are LifePartner and six venture-specific controls. Hence, for example, male entrepreneurs who have a life partner, run a larger venture, have previous relevant work experience, have few time-demanding side-activities, who outsource business tasks, and who are able to keep up with industry developments, tend to have relatively high monthly revenues. This provides support for a indirect effect of performance next to the direct effects. ${ }^{10}$

\section{Discussion and Conclusions}

This study empirically investigates factors that influence satisfaction levels of recently established entrepreneurs. We find that founders differ in terms of the degree of satisfaction with income, psychological well-being and leisure time. More specifically, founders with high levels of human capital specific to the firm are more satisfied with income than those with high levels of general human capital. Job similarity has both a direct and indirect positive effect (via business performance) on satisfaction with income. Founders who are driven by intrinsic (instead of extrinsic) motivation or who start a business to combine responsibilities, are better able to cope with stress and are more satisfied with their leisure time. This supports Hamilton's (2000) notion that many self-employed are motivated by non-pecuniary benefits.

Women are more satisfied with their income than men, even though they have a lower average monthly turnover. Women find it more difficult to cope with stress and are less satisfied with their leisure time. Although having a life partner does not contribute to entrepreneurial satisfaction, it does have a positive effect on performance, thereby indirectly affecting satisfaction with income. Entrepreneurs reporting high risk tolerance are more satisfied with their income and are less bothered by stress. Risk tolerant entrepreneurs apparently anticipate on possible set-backs associated with starting a new venture.

Venture-specific characteristics influence entrepreneurial satisfaction mainly indirectly through performance. There is an interesting combination of effects of start-up capital on satisfaction. On the one hand, the amount of start-up capital reduces satisfaction with income directly. This can be attributed to high expectations. On the other hand, the amount of start-up capital enhances business performance, which again indirectly boosts satisfaction. These two effects appear to cancel out. Also, entrepreneurs who run firms in complex environments and lack relevant experience are prone to dissatisfaction, due to, for example, potential pitfalls, underestimation of competition, project duration and the difficulty of finding customers.

Higher firm performance per se does not lead to more happiness among founders. It does not guarantee a higher overall level of satisfaction. Firm performance (of course) increases satisfaction with income, but this comes at the price of lower satisfaction with leisure time.

\footnotetext{
${ }^{9}$ We also estimated an ordered logit model because of the categorical nature of the performance variable. There is no change in the significance of the variables as compared to the OLS results.

${ }^{10}$ We have also applied a randomly split sample approach to investigate robustness of our results and found estimates to be reasonably stable.
} 
We mention three limitations of our study. First, the study deals with one country, that is, the Netherlands. Second, we use cross-sectional data, which makes it difficult to test for causality. However, most independent variables are based upon items of an objective nature (facts), limiting problems of reversed causality. Third, we use self-reported data for satisfaction. This may lead to some form of cognitive dissonance, where respondents compare business outcomes to their labor market situation prior to start-up instead of taking into account their initial expectations.

Open Access This article is distributed under the terms of the Creative Commons Attribution Noncommercial License which permits any noncommercial use, distribution, and reproduction in any medium, provided the original author(s) and source are credited.

\section{References}

Amit, R., MacCrimmon, K. R., Zietsma, C., \& Oesch, J. M. (2001). Does money matter? Wealth attainment as the motive for initiating growth-oriented technology ventures. Journal of Business Venturing, 16(2), $119-143$.

Andersson, P. (2008). Happiness and health: Well-being among the self-employed. The Journal of SocioEconomics, 37, 213-236.

Arabsheibani, G., de Meza, D., Maloney, J., \& Pearson, B. (2000). And a vision appeared upon them of a great profit: evidence of self-deception among the self-employed. Economics Letters, 67(1), 35-41.

Åstebro, T., Jeffrey, S. A., \& Adomdza, G. K. (2007). Inventor perseverance after being told to quit: The role of cognitive biases. Journal of Behavioral Decision Making, 20, 253-272.

Becker, G. S. (1993). Nobel lecture: The economic way of looking at behavior. Journal of Political Economy, 101, 385-409.

Benz, M., \& Frey, B. S. (2004). Being independent raises happiness at work. Swedish Economic Policy Review, 11, 95-134.

Benz, M., \& Frey, B. (2008a). Being independent is a great thing: Subjective evaluations of self-employment and hierarchy. Economica, 75, 362-383.

Benz, M., \& Frey, B. S. (2008b). The value of doing what you like: Evidence from the self-employed in 23 countries. Journal of Economic Behavior and Organization, 68, 445-455.

Beyer, S., \& Bowden, E. M. (1997). Gender differences in self-perceptions: Convergent evidence from three measures of accuracy and bias. Personality and Social Psychology Bulletin, 23, 157-172.

Bhandari, G., \& Deaves, R. (2006). The demographics of overconfidence. Journal of Behavioral Finance, 7(1), 5-11.

Blanchflower, D. G., \& Oswald, A. J. (1998). What makes an entrepreneur? Journal of Labor Economics, 16(1), 26-60.

Block, J., \& Koellinger, P. (2009). I can't get no satisfaction-Necessity entrepreneurship and procedural utility. Kyklos, 62(2), 191-209.

Boes, S., Staub, K., \& Winkelmann, R. (2010). Relative status and satisfaction. Economics Letters, 109(3), $168-170$.

Bonke, J., Deding, M., \& Lausten, M. (2009). Time and money: A simultaneous analysis of men's and women's domain satisfactions. Journal of Happiness Studies, 10, 113-131.

Bradley, D. E., \& Roberts, J. A. (2004). Self-employment and job satisfaction: Investigating the role of selfefficacy, depression, and seniority. Journal of Small Business Management, 42(1), 37-58.

Busenitz, L. W., \& Barney, J. B. (1997). Differences between entrepreneurs and managers in large organizations: Biases and heuristics in strategic decision-making. Journal of Business Venturing, 12, 9-30. 4.

Camerer, C., \& Lovallo, D. (1999). Overconfidence and excess entry: an experimental approach. American Economic Review, 89(1), 306-318.

Carree, M. A., \& Nijkamp, J. (2001). Deregulation in retailing: The Dutch experience. Journal of Economics and Business, 53, 225-235.

Castanias, R. P., \& Helfat, C. E. (2001). The managerial rents model: Theory and empirical analysis. Journal of Management, 27(6), 661-678.

Clark, A. E. (1997). Job satisfaction and gender: Why are women so happy at work. Labour Economics, 4, 341-372. 
Clark, A. E., \& Oswald, A. J. (1996). Satisfaction and comparison income. Journal of Public Economics, 61, 359-381.

Clark, A., Oswald, A., \& Warr, P. (1996). Is job satisfaction U-shaped in age? Journal of Occupational and Organizational Psychology, 69, 57-81.

Cooper, A. C., \& Artz, K. W. (1995). Determinants of satisfaction for entrepreneurs. Journal of Business Venturing, 10, 439-457.

Cooper, A. C., Woo, C. Y., \& Dunkelberg, W. C. (1988). Entrepreneurs' perceived chance of success. Journal of Business Venturing, 3(3), 97-108.

Feldman, D. C., \& Bolino, M. C. (2000). Career patterns of the self-employed: career motivations and career outcomes. Journal of Small Business Management, 38(3), 53-67.

Ferrante, F. (2009). Education, aspirations and life satisfaction. Kyklos, 62(4), 542-562.

Ferrer-i-Carbonell, A., \& Frijters, P. (2004). How important is methodology for the estimates of the determinants of happiness? Economic Journal, 114, 641-659.

Forbes, D. P. (2005). Are some entrepreneurs more overconfident than others? Journal of Business Venturing, 20, 623-640.

Fraser, S., \& Greene, F. J. (2006). The effects of experience on entrepreneurial optimism and uncertainty. Economica, 73, 169-192.

Fuchs-Schündeln, N. (2009). On preferences of being self-employed. Journal of Economic Behavior and Organization, 71, 162-171.

Gazioglu, S., \& Tansel, A. (2006). Job satisfaction in Britain: individual and job related factors. Applied Economics, 38, 1163-1171.

Gilad, B., \& Levine, P. (1986). A behaviour model of entrepreneurial supply. Journal of Small Business Management, 24, 45-51.

Hamilton, B. H. (2000). Does entrepreneurship pay? An empirical analysis of the returns to self-employment. Journal of Political Economy, 108(3), 604-631.

Hayward, M. L. A., Shepherd, D. A., \& Griffin, D. (2006). A hubris theory of entrepreneurship. Management Science, 52(2), 160-172.

Hundley, G. (2001). Why and when are the self-employed more satisfied with their work? Industrial Relations, 40(2), 293-316.

Jamal, M. (1997). Job stress, satisfaction, and mental health: an empirical examination of self-employed and non-self-employed Canadians. Journal of Small Business Management, 35(4), 48-57.

Kahneman, D., \& Lovallo, D. (1993). Timid choices and bold forecasts: a cognitive perspective on risk taking. Management Science, 39(1), 17-31.

Katz, J. A. (1993). How satisfied are the self-employed: A secondary analysis approach. Entrepreneurship Theory and Practice, 17(3), 35-50.

Kihlstrom, R. E., \& Laffont, J. J. (1979). A general equilibrium entrepreneurial theory of firm formation based on risk aversion. Journal of Political Economy, 87, 719-748.

Lundeberg, M. A., Fox, P. W., \& Puncochar, J. (1994). Highly confident but wrong: Gender differences and similarities in confidence judgments. Journal of Educational Psychology, 86, 114-121.

Parasuraman, S., \& Simmers, C. A. (2001). Type of employment, work-family conflict and well-being: A comparative study. Journal of Organizational Behavior, 22, 551-568.

Parker, S. C. (2006). Entrepreneurs as producers. In S. Parker (Ed.), The life cycle of entrepreneurial ventures (pp. 337-360). Berlin: Springer.

Peterson, R. A., \& Wilson, W. R. (1992). Measuring customer satisfaction: fact and artifact. Journal of the Academy of Marketing Science, 20(1), 61-71.

Phillips, B. D., \& Kirchoff, B. A. (1989). Formation, growth and survival: Small firm dynamics in the US economy. Small Business Economics, 1, 65-74.

Salinas-Jiménez, M., Artés, J. \&J. Salinas-Jiménez, (2010). Income, motivation, and satisfaction with life: An empirical analysis, Journal of Happiness Studies, forthcoming.

Sarasvathy, D. K., Simon, H. A., \& Lave, L. (1998). Perceiving and managing business risks: Differences between entrepreneurs and bankers. Journal of Economic Behavior and Organization, 33, 207-225.

Scarpello, V., \& Campbell, J. (1983). Job satisfaction: Are all parts there? Personnel Psychology, 36(3), $577-600$.

Senik, C. (2009). Direct evidence on income comparisons and their welfare effects. Journal of Economic Behavior and Organization, 72(1), 408-424.

Simon, M., \& Houghton, S. M. (2003). The relationship between overconfidence and the introduction of risky products: Evidence from a field study. Academy of Management Journal, 46(2), 139-150.

Stutzer, A. (2004). The role of income aspirations in individual happiness. Journal of Economic Behavior and Organization, 54(1), 89-109. 
Thompson, C. A., Kopelman, R. E., \& Schriescheim, C. A. (1992). Putting all eggs in one basket: A comparison of commitment and satisfaction among self and organizationally employed men. Journal of Applied Psychology, 77(5), 738-743.

VandenHeuvel, A., \& Wooden, M. (1997). Self-employed contractors and job satisfaction. Journal of Small Business Management, 35(3), 11-20.

Vermeulen, M., \& Mustard, C. (2000). Gender differences in job strain, social support at work, and psychological distress. Journal of Occupational Health Psychology, 5(94), 428-440.

Wanous, J. P., Reichers, A. E., \& Hudy, M. J. (1997). Overall job satisfaction: how good are single-item measures? Journal of Applied Psychology, 82(2), 247-252.

Wellington, A. J. (2006). Self-employment: the new solution for balancing family and career? Labour Economics, 13, 357-386.

Wright, M., Robbie, K., \& Ennew, C. (1997). Venture capitalists and serial entrepreneurs. Journal of Business Venturing, 12, 227-249. 